\title{
Disaggregating Civility: Politeness, Public-Mindedness and Their Connection
}

\author{
Aurélia Bardon $^{1}$ (D), Matteo Bonotti ${ }^{2 \star}$ (D), Steven T. Zech ${ }^{2}$ (D) and William Ridge ${ }^{3}$ \\ ${ }^{1}$ University of Konstanz, Konstanz, Germany, ${ }^{2}$ Monash University, Melbourne, Australia and ${ }^{3}$ University of Melbourne, \\ Melbourne, Australia \\ * Corresponding author. Email: matteo.bonotti@monash.edu
}

(Received 12 March 2021; revised 29 July 2021; accepted 10 November 2021; first published online 11 February 2022)

\begin{abstract}
Calls for civility feature prominently in public discourse, and the concept has received growing attention by political philosophers recently. But what does it mean to be civil? The existing literature distinguishes between two main understandings of civility: civility as politeness and civility as public-mindedness. The objective of this article is to show that these conceptions and the different normative claims associated with them can all fit together. We argue that civility and incivility should be disaggregated in order to uncover fruitful connections between different aspects of the concept. We introduce a distinction between two dimensions of civility as public-mindedness (moral and justificatory), as well as a new distinction between the means and ends of civility. We examine the complex connections between the different dimensions of (in)civility and show that the disaggregation of civility and incivility tells us what kind of (in)civility matters, as well as when and why.
\end{abstract}

Keywords: Civility; Civility as politeness; Civility as public-mindedness; Moral civility; Justificatory civility

At the 2020 State of the Union address, Nancy Pelosi ripped up a copy of the speech that Donald Trump had just given. Trump's opponents applauded her for it, but his supporters called her 'nasty' and 'disrespectful'. They viewed that act as yet another example of the decline in civility in the United States that pundits have lamented for decades. Pelosi responded that it was actually the 'courteous thing to do', adding later that Trump's address was a 'manifesto of mistruths'. Incivility, she suggested, was more to be found in the content of the speech than in the ripping up of a piece of paper (Greve and Pilkington 2020).

The concept of civility often features prominently in public discourse - or, rather, accusations of incivility do. Civility is usually considered a basic and necessary public virtue, and at the same time, many are worried that it is slowly disappearing. Politics, it is said, has become less and less civil. Debate does not produce fruitful disagreements, but rather heated exchanges, pointless clashes and 'wars of words' (Bejan 2017,2). The situation is only made worse by greater political polarization along partisan lines. Calls for civility come from all sides, but a consensus on what it means to be civil or uncivil remains elusive.

Disagreements regarding what civility means or entails also take place among political philosophers. Existing academic work seems to offer two main understandings of civility. On the one hand, some scholars view civility as tied to norms of politeness and etiquette. On the other hand, civility is understood in a more political sense, as captured, for example, by Rawls's (2005) idea of the 'duty of civility', that is, the duty to only appeal to public reasons in order to justify political rules. The normative claims associated with different understandings of civility vary significantly.

(C) The Author(s), 2022. Published by Cambridge University Press. This is an Open Access article, distributed under the terms of the Creative Commons Attribution licence (http://creativecommons.org/licenses/by/4.0/), which permits unrestricted re-use, distribution and reproduction, provided the original article is properly cited. 
Some philosophers argue that civility is required as a functional tool to make life in society possible (Boyd 2006; Lægaard 2010) and others that it is a moral obligation that we owe to those we live among (Buss 1999). Some argue that civility fosters inclusion (Cohen 2012), and others criticize it as an instrument of exclusion (Delmas 2018; Zerilli 2014).

It might seem at first that these different conceptions and the different normative claims associated with them cannot all fit together - that some must be wrong and others must be right. The objective of this article is to show that this is not the case. The different claims in the philosophical literature about civility can be reconciled. Our central claim is that we should disaggregate civility and incivility in order to uncover fruitful connections between different aspects of the concept. First, we acknowledge and defend the distinction between two kinds of civility, which we call 'civility as politeness' and 'civility as public-mindedness'. We further distinguish between two dimensions of civility as public-mindedness: 'justificatory civility' and 'moral civility'. We then introduce a new distinction between the means and ends of civility that brings to light the hierarchical relationships between the different kinds of civility: civility as public-mindedness has priority over civility as politeness; and moral civility has priority over justificatory civility. Lastly, we examine the complex connections between the different dimensions of (in)civility; in particular, we show that incivility as impoliteness and justificatory incivility can actually serve the end of moral civility. The article provides a critical survey of the philosophical literature on civility and, at the same time, contributes to that debate by showing how civility presents different dimensions and how these different dimensions and the normative claims associated with them can be reconciled to form a full and internally consistent concept of civility. Ultimately, disaggregating both civility and incivility is necessary to tell us what kind of (in)civility matters, as well as when and why.

\section{Civility as Politeness and Civility as Public-Mindedness}

The concept of civility has been extensively examined in the sociological literature, for example, in sociological classics like Norbert Elias's (1969) The Civilizing Process and Erving Goffman's (1959) The Presentation of Self in Everyday Life. Much of the contemporary philosophical analysis of civility draws on and departs from those works in order to develop sophisticated conceptual and normative accounts of the concept. Many philosophers have made a distinction between two conceptions of civility: between civility as mere tolerance and civility as affirmation of the ends that others pursue (Sinopoli 1995, 612); between political and polite civility (Calhoun 2000, 255); between formal and substantive civility (Boyd 2006, 864); between civility of etiquette and liberal civility (Meyer 2000, 71); between civility as an ethical concept and civility as a political concept (Edyvane 2017, 345); between 'civility as politeness' and 'civility as responsiveness' (Laden 2019); and between 'mere civility' and 'more robust conceptions' (Bejan 2017, 159). The details of these distinctions vary, but all of them ultimately share the idea that a distinction should be made between a 'thin' and a 'thick' version of civility, that is, between a more or less minimal or superficial compliance with social norms and a deeper commitment to moral and political principles based on respect for others. We also embrace this twofold characterization of civility and call the thin version 'civility as politeness' and the thick version 'civility as publicmindedness. ${ }^{1}$ We examine the two dimensions of civility in turn.

\section{Civility as Politeness}

Civility is often understood as a virtue associated with etiquette and good manners. For instance, according to Edyvane $(2017,345)$, 'civility is bound up with the idea of what it means to be

\footnotetext{
${ }^{1}$ For additional discussion of the various dimensions of civility and examples of how they play out in practice, see Bonotti and Zech (2021).
} 
civilized, to be well-mannered or polite; its focus is on standards of behaviour in our dealings with others in everyday life'. Some authors refer to this kind of civility as 'ethical civility' (Edyvane 2017, 345) or as a 'moral virtue' (Calhoun 2000, 273). However, politeness is a more accurate and clearer way to define this first kind of civility, since one can be polite towards others and respect the rules of etiquette for non-moral reasons, without acknowledging the moral worth of others. For example, to label civility as 'politeness' 'ethical civility' or 'moral virtue' would prove contentious in the context of a racist politician who uses polite speech or behaviour to advance a racist agenda. The politician exhibits only a surface-level kind of politeness, lacking any (positive) moral connotations. ${ }^{2}$

Civility in this sense involves not only a list of dos and don'ts for everyday life, including how to greet people and how to behave in particular scenarios (for example, not jumping the queue, not speaking loudly on the phone in public and so on), but also a 'set of habits of speaking and listening' (Bejan 2017, 164) that tells us more specifically how we should talk to others, especially when we happen to disagree with them: we should avoid offensive language, we should listen to what others have to say, we should not interrupt them, we should not be dismissive in how we respond to them and so on. Civility as politeness is just enough to make disagreeing possible and tolerable, 'even - and especially - in the absence of actual respect or affirmation' (Bejan 2011, 417); for this reason, this 'mere civility' defended by Bejan is kept distinct from the much more demanding values of recognition or mutual respect. What civility as politeness demands is not the recognition of others' equal moral worth but merely the recognition of others' status as co-members of society with whom we must coexist. As Edyvane (2020, 95, emphasis in original) notes, politeness 'implies recognition of members of the group as enjoying a certain standing in relation to the problem of sociation', but it does not necessarily imply 'that I think you [are] entitled to an equal say'. It therefore seems misleading to call such a thin conception of civility 'moral', which is why we prefer the term 'civility as politeness'.

Civility as politeness inherently depends on 'generally agreed upon, often codified, social rules' (Calhoun 2000, 260). Crucially, these rules are neither universal nor static; rather, they are based on customs, which are relative and vary between societies (Kekes 1984; Sinopoli 1995). Noting a similar idea in his analysis of the French face-veiling debates, Daly $(2015,313)$ points out how 'the bodily and linguistic techniques that constitute republican civility [as politeness] are highly encoded partly because they embrace a situational or cultural specificity which will appear arbitrary and perhaps incomprehensible to those not already endowed with it'. Relatedly, Strachan and Wolf $(2012,402)$ lament the fact that 'measuring the level of civility present in society ... is especially difficult because the specific behaviours defined as appropriate in one culture, or even in different settings within the same culture, can be inappropriate in others'. ${ }^{3}$ Cultural

\footnotetext{
${ }^{2}$ That racist speech can be more or less polite is clear if we consider different typologies of hate speech. On the one hand, we might consider what is normally referred to as 'fighting words', i.e., insulting and derogatory speech that intends/is likely to cause immediate (violent) reaction by the target (see Chaplinsky v. New Hampshire [1942] 315 U.S. 568). When neo-Nazis or other racist people use this kind of hate speech, they are likely to provoke a total closure on the part of their interlocutors, thus precluding any kind of social interaction. On the other hand, think of instances of hate speech involving group defamation, e.g., statements such as 'all X are criminals' or 'all X are terrorists'. If conveyed in a superficially polite way, e.g., without comparing $\mathrm{X}$ to vermin or using derogatory language, these statements may not cause closure, and according to some, they may in fact stimulate some kind of public debate, which is a form of social interaction (e.g., Brown 2015, 106ff). There are, of course, many other problems with these statements (e.g., they are false, misleading, etc.), but their form and tone may display a minimal willingness to engage in social interaction that more impolite and derogatory forms of hate speech lack.

${ }^{3}$ Bejan $(2017,41)$ makes a similar point when she argues that 'civility is ... a vexingly capacious concept with distinctive resonances in different linguistic and cultural traditions'. Furthermore, it is precisely through her comprehensive historical analysis of these different traditions that Bejan is able to distinguish between civility and other conversational virtues that are often (and, in her view, mistakenly) equated with civility. These include 'the Italian civiltà and vivere civile [that] emphasized urban living, republicanism, and civic virtue, the French discourse of courtoisie, civilité, and politesse [that] was more status conscious, courtly, and aristocratic ... and [t]he English civilitie [that], by contrast, rejected complicated forms of address and byzantine rituals of mutual compliment in favour of ideas of "gentleness" and "good breeding"' (Bejan 2017, 42, emphasis in original).
} 
and social norms dictate what counts as civil, and yet cultural and social norms are likely to differ significantly between different contexts and to change relatively rapidly even within the same society.

This poses another problem. The historically and culturally contingent nature of civility (as politeness) is also sometimes linked to its alleged 'dark side' (Bejan 2017, 9) and to the view that civility may be a vehicle for oppression, silencing and exclusion. As Elias (1969) and Freud (2004) have famously argued, and as Bejan aptly reminds us, given that its norms are often developed against the structural background of pre-existing power asymmetries, civility could be considered by some as irremediably imbricated with colonialism and empire ... a covert demand for conformity that delegitimizes dissent while reinforcing the status quo' (Bejan 2017, 9). When that is the case, potential responses may include 'incivility as dissent' (Edyvane, 2020), that is, deliberate acts of incivility aimed at expressing a sense of injustice towards established social norms, structures and institutions. ${ }^{4}$

\section{Civility as Public-Mindedness}

Alongside the thin conception that we label 'civility as politeness', some scholarship views civility primarily as a political concept, describing it as a civic virtue that relates to liberal politics (Edyvane 2017; Meyer 2000). This understanding of civility focuses on an individual's responsibilities as a member of a liberal-democratic political community. Echoing and expanding on this sentiment, Edyvane $(2017,345)$ notes how this notion of civility is bound up with the idea of an association of citizens, and includes cognate ideas of the civic, the civil and the civilian; it concerns one's status and duties as a member of a political community, as a citizen with certain rights and responsibilities'. This characterization of civility highlights the importance for individuals to adhere to core liberal-democratic values in a way that takes into account the collective good. In other words, those who are civil in this political sense engage in 'a kind of politics, a type of political discourse that does not harm, injure, or offend fellow citizens' (Harcourt 2012, 5). ${ }^{5}$ A civility that entails a regard for the broader public improves democratic governance and social coexistence in the long term.

This second kind of civility is often simply called 'political civility' (Edyvane 2017, 345), but we believe that 'civility as public-mindedness' is a more accurate term. It is not merely civility applied to the political sphere; instead, it is a kind of civility characterized by an attitude of giving proper weight and recognition to others as free and equal members of society. Those adhering to civility as public-mindedness demonstrate a deep moral commitment to liberal political values and institutions (Macedo 1992), and it is in this sense that civility is considered a core liberal value (Boyd 2006, 863; Meyer 2000, 79; Rawls 2005, 217; Sabl 2005, 219). While politeness is not necessarily absent from civility as public-mindedness, the distinction between the two dimensions is important. It helps us to highlight that one can be perfectly civil in the sense of politeness without adhering to any of the rules of civility as public-mindedness tied to specific liberal and democratic commitments. ${ }^{6}$

Bejan (2017, 9, emphasis in original) contrasts these conversational virtues with what she calls 'mere civility: a minimal conformity to norms of respectful behaviour and decorum expected of all members of a tolerant society as such'. According to Bejan, mere civility pertains, in particular, to disagreements between co-members of the same civil society.

${ }^{4} \mathrm{We}$ will return to this point in the final section before the Conclusion, where we examine the relationship between the different (sub-)dimensions of civility.

${ }^{5} \mathrm{~A}$ critic might argue that perfectly civil disagreements can nevertheless offend plenty of people, i.e., that disagreement itself can be offensive. However, we reject this view. We believe that Harcourt's inclusion of 'does not offend' under the definition of civility should not be understood as implying that civility does not allow one to disagree with others. Disagreement is, of course, inherent in most social and political communities, and some people may even be upset by this fact. However, we do not believe that disagreement itself is offensive. In making this claim, we draw on Joel Feinberg's classic definition of offence: 'I am offended (or "take offense") when (a) I suffer a disliked state, and (b) I attribute that state to the wrongful [i.e., right-violating] conduct of another, and (c) I resent the other for his role in causing me to be in the state' (Feinberg 1985,2 , emphasis in original). We do not think that disagreement itself constitutes an offense thus understood (particularly with regard to Feinberg's second condition).

${ }^{6}$ Bejan $(2017,164)$ acknowledges explicitly, for instance, that 'mere civility is not necessarily a democratic virtue'. 
We believe that it is useful to distinguish between two different sub-dimensions of civility as public-mindedness. The first sub-dimension focuses on one's duties towards others regarding the justification of political decisions. We call this 'justificatory civility'. Rawls $(2005,217)$ introduces and defends the most prominent account of this first sub-dimension of public-mindedness in what he refers to as the 'duty of civility'. This notion of political civility corresponds with the 'practice of reasonable public discourse' (Meyer 2000, 72): the policies that one advocates should be justified by appealing only to public reasons, that is, reasons that all persons in a diverse society could understand and accept at some level of idealization. It is also interestingly related to Hobbes's conception of civility as a 'civil silence on controversial questions' (Bejan 2017, 13): if we simply do not discuss controversial questions, then we avoid any unpleasant disagreements. The Rawlsian duty of civility equally proposes to bracket comprehensive doctrines, which are the object of fundamental disagreement. Justificatory civility, then, is primarily a 'method of avoidance' (Zerilli 2014, 123). By complying with the duty of civility, members of society treat each other as free and equal and contribute to realizing an 'overlapping consensus' (Rawls 2005) between different conceptions of the good. Meyer $(2000,75)$ articulates how this kind of 'consensus is an admirable achievement - not only because it can help avert some serious conflict, but also because it is a necessary step toward the creation of a coherent, pluralistic civil realm'.

Justificatory civility tells us not merely how to speak to others in general but, more specifically, how we should justify political rules in ways that respect the liberal principle of legitimacy. According to the latter, "[o]ur exercise of political power is fully proper only when it is exercised in accordance with a constitution the essentials of which all citizens as free and equal may reasonably be expected to endorse in the light of principles and ideals acceptable to their common human reason' (Rawls 2005, 137). To be civil in the justificatory sense means to comply with the demands of public reason. This requires refraining from invoking our comprehensive doctrines when justifying political rules and appealing instead to political values that are widely endorsed in liberal-democratic societies. These include: individual rights and liberties, equality of opportunity, and the promotion of the common good; guidelines of inquiry, that is, 'principles of reasoning and rules of evidence in the light of which citizens are to decide whether substantive principles properly apply and to identify laws and policies that best satisfy them'; and 'the methods and conclusions of science when these are not controversial' (Rawls 2005, 224). As Cohen $(2012,119-20)$ puts it, this kind of civility is not about politeness and 'how we talk to our friends or students or members of our neighborhood or church or union or company', but about politics and 'how we ought to argue with others on basic political and constitutional questions'. By complying with the constraints of public reason, we communicate our respect for other members of society as free and equal persons. In the recent literature in liberal political philosophy, this is often how civility is understood.

The second sub-dimension of civility as public-mindedness - what we call 'moral civility' also involves recognizing others as free and equal. However, unlike justificatory civility, moral civility does not relate to the justificatory status of the reasons used to support political decisions. What matters here is not whether we use the language of public reason when justifying political rules but whether our words or actions express the right kind of moral commitments towards others. More specifically, being morally civil involves recognizing others as free and equal by refraining from infringing upon their fundamental rights, liberties and equal civic standing. This may require, for example, refraining from the use of physical violence (Zurn 2013), discrimination (Peterson 2019) or racist or hateful speech that characterizes members of certain groups (for example, women or minority ethnic groups) as holding a lesser status in some way (see, for example, Waldron 2012a; see also Bejan 2017, 7).

Moral civility is the sub-dimension of civility (as public-mindedness) that comes closest to the value of respect and sometimes appears barely distinguishable from it: civility is indeed said to be a 'form of trust and mutual respect or recognition' (Pippin 2005, 226), and the 'democratic value of mutual respect' is said to be the 'key value' in discussions about civility (Christiano 2012, 113). 
Civility in this sense 'presupposes an active and affirmative moral relationship between persons' (Boyd 2006, 875). It is something like moral civility that Bejan (2017, 159-160, emphasis in original) has in mind when she criticizes the 'reductio ad respectum' that she sees in the work of many contemporary political theorists, for whom " "[c]ivility" becomes... just another example of our respect or recognition of others' equal dignity, rather than a distinct or distinctive virtue'.

However, and as we will explain more extensively in the next section, moral civility (like the other [sub-]dimensions of civility) concerns not how we treat others per se, but rather the kind of moral commitment that we are communicating to others when we treat them (or, in the case of moral incivility, do not treat them) in a certain way. More specifically, moral civility involves displaying or communicating to others, through one's speech and/or behaviour, that we respect them as free and equal members of society. Indeed, as Calhoun (2000, 261-2) points out, one can be respectful (or tolerant or considerate) towards others without actually being civil or uncivil - for example, someone who donates to charities without knowing (or being known by) their beneficiaries. Conversely, one can be disrespectful towards others, for example, by engaging in covert criminal activities, without being uncivil, that is, without communicating any disrespect to their victims or to other members of society more broadly (Calhoun 2000, 261). Furthermore, in some cases, one can be both respectful and uncivil at the same time for example, an employer who fully complies with affirmative action regulations but who says to the new employee, '[y]ou know you only got this job because you're black' (Calhoun 2000, 261).

In sum, moral civility and incivility involve some kind of communicative interaction with others, rather than merely treating others in a respectful or disrespectful way. While our speech always involves a communicative dimension - for example, using (or refraining from using) hate speech clearly communicates disrespect (or respect) towards one's audience - our behaviour can also communicate respect or disrespect for others. For example, depending on when, where, why and how they are performed, acts of non-violent (civil) or violent (uncivil) protest can be highly communicative and publicly display our moral commitment to liberal-democratic values and to respecting others as free and equal persons, or lack thereof, respectively.

The distinction between the justificatory and moral sub-dimensions of civility as publicmindedness becomes particularly clear if we consider that adherence to the latter does not always imply adherence to the former. One could hold a firm commitment to liberal-democratic values, such as non-discrimination and non-violence, while appealing to non-public reasons to support political rules that advance them. For example, Rawls (2005) refers to the case of those abolitionists who explicitly used religious reasons to justify the abolition of slavery in the United States and

\footnotetext{
${ }^{7}$ Here, we would like to consider and reject the potential criticism that moral and justificatory civility are inherently tied to liberal-democratic societies and therefore, like civility as politeness (see earlier), may be vehicles for a form of cultural imperialism. While the framework that we present in this article is mainly centred around liberal-democratic understandings of moral and justificatory civility, we believe that it is portable across different social and political contexts, including non-liberal ones. More specifically, along with different context-related norms of civility as politeness (an aspect that we have already considered earlier), we believe that there are also different types of context-related moral and justificatory civility. With regard to moral civility, consider, for example, Rawls's (1999) famous distinction between 'liberal' and 'decent' societies in The Law of Peoples. Decent societies, Rawls argues, include hierarchical ones where basic human rights and hierarchical consultation mechanisms are present but that are not centred around the liberal ideal of members of society as free and equal (e.g., only members of the dominant religious group can access public office). It could be argued that in these societies moral civility involves the affirmation of a different type of moral relationship than is the case in liberal-democratic societies, i.e., one that includes toleration and non-discrimination but not the recognition of others as free and equal. Likewise, while the kind of justificatory civility that we discuss in this article is inherently liberal, norms of public reason and public justification can also exist in non-liberal societies (see, e.g., Salam 2019). In these contexts, therefore, justificatory civility will look different from what it is in liberal-democratic societies. Furthermore, norms of moral and justificatory civility, like norms of civility as politeness, can also change over time within the same society (see, e.g., Flanders 2012). While we do not have the space to further explore these issues in the present article, we believe that the portability of our framework between contexts and across time can both help stimulate future research on the three dimensions of civility (including in non-liberal contexts) and provide a response to those who might raise the issue of cultural imperialism.
} 
therefore advance liberal-democratic norms and institutions. Slavery, they argued, was simply 'contrary to God's law' (Rawls 2005, 249); this would be consistent with moral civility but not with justificatory civility.

Conversely, justificatory civility does not always entail moral civility. Consider, for example, how over the past few decades, far-right political actors have made an increasing use of liberal values in their rhetoric to publicly justify and legitimize their exclusionary political agendas. As one scholar observes:

in recent decades ... researchers have focused attention on far-right parties' attempts to construct a 'civic' discourse based on liberal - as opposed to illiberal - values, as the far right comes to recognise that national identities are increasingly predicated on liberal and civic terms... To achieve acceptability in mainstream society, in fact, a number of far-right groups now mobilise strategically on liberal and progressive values, targeting the cultural identity of specific groups of migrants, and their supposed incompatibility with liberal principles such as gender equality, free speech and secularism (Castelli Gattinara 2017, 346).

Liberal principles, such as free speech and gender equality, are clearly values central to the public political culture of liberal-democratic societies and, therefore, to public reason and justificatory civility. However, by appealing to them strategically in order 'to make exclusionism appear liberal and progressive and therefore more acceptable in democratic societies' (Castelli Gattinara 2017, 360), far-right political actors de facto employ justificatory civility in order to advance morally uncivil goals. We will return to these points in the final section before the Conclusion, where we examine different types of functional congruence and incongruence between the various (sub-)dimensions of civility.

\section{The Means and Ends of Civility}

The distinction between civility as politeness and civility as public-mindedness, and between justificatory and moral civility under the latter, is analytically useful. As we have already pointed out, while using labels different from ours, other scholars have also made a distinction between two dimensions of civility. It should also be noted that some of these scholars argue that even when we are in the presence of two distinct dimensions of civility, there is an overlap or connection between them, and that the distinction should therefore not be understood as a full separation (Boyd 2006, 864; Edyvane 2017, 345; Meyer 2000, 73; Shils 1997, 339). However, we argue that the distinction between the two dimensions of civility should be reconceptualized as one between the means and the ends of civility. This kind of distinction has been largely ignored in the literature so far. We will show that it provides a valuable approach to understanding what kind of civility matters, as well as when and why.

As we have already pointed out, the different dimensions of civility identified in the previous section all share the same basic idea that civility is about the expression of some form of respect, rather than simply or directly a form of respect. Civility is an 'essentially communicative form of moral conduct', which 'always involves a display of respect, tolerance, or considerateness' (Calhoun 2000, 260, 259 , emphasis in original), and sends a 'signal' to other members of society, 'marking them as fully equals' (Carter 1998, 11). It is therefore not merely or necessarily about respecting others, but about telling others that we are respecting them, about 'appearing respectful' (Buss 1999).

If civility is characterized as a communicative act, then it is important to distinguish between what it is meant to communicate and how this is done, that is, why and how one should be civil. The former question focuses on the ends of civility and the latter focuses on the means of civility. ${ }^{8}$

\footnotetext{
${ }^{8}$ Edyvane (2017, 346, emphasis in original) makes a very similar point: '[ $t$ ]he idea of civility has two components: (1) a pattern of conduct that expresses (2) a particular attitude towards others'. However, Edyvane does not use the distinction
} 
Both civility as politeness and civility as public-mindedness focus on how civility is expressed. Each conception of civility identifies particular rules that are meant to express a form of respect for others, and being civil means accepting and applying these rules. The rules of politeness are fairly thin and related to what it means to be civilized, whereas public-mindedness entails more substantive political principles related to what it means to be a good citizen.

However, it is also important to see how politeness and public-mindedness aim at expressing different things: they are different not only in their means, but also in their ends. Although both can be said to express some form of respect, civility as politeness and civility as publicmindedness are based on different understandings of respect. To explain this, we rely on Darwall's (1977) distinction between 'recognition respect' and 'appraisal respect'. While appraisal respect involves a positive evaluation of others' merits and achievements, recognition respect involves 'giving appropriate consideration or recognition to some feature of its object in deliberating about what to do' (Darwall 1977, 38). Displaying recognition respect towards other members of society involves respecting them for the status they enjoy and for the rights and freedoms associated with that status. Lægaard $(2010,12)$ highlights the centrality of recognition respect in civility when he notes how 'the kind of respect communicated by civility is more formal than the positive respect for specific differences proposed by many multiculturalists, precisely because it does not concern specific differences but generic equality'. Recognition respect is involved in civility as politeness and in the two sub-dimensions of civility as public-mindedness. ${ }^{9}$ However, different conceptions of the status of others are at work in each (sub-)dimension.

Civility as politeness only involves a very basic form of respect, that is, a 'minimal public deference - a mere forbearance from roughness or unpleasantness' (Manning 1976, 13). It concerns 'the conditions under which citizens retain self-respect while negotiating fleeting public encounters' (Manning 1976, 13). By complying with norms of etiquette and good manners, we display this minimal form of respect towards others. This, however, does not require that we recognize their status as free and equal members of society. This is a pragmatic and very minimal kind of respect, as when we 'respect' the queue in a shop or simply acknowledge the presence of another with a cordial greeting. Civility as politeness can be motivated by purely pragmatic reasons. Indeed, one of its key functions is to allow for and promote a peaceful 'unmurderous coexistence' (Bejan 2017, 166) between individuals who do not agree with each other but have to live together in the same society (Boyd 2006, 865). Civility, in this sense, is necessary for the 'containment of conflicts' (Edyvane 2017, 348). Lægaard $(2010,12)$ actually describes this as the primary function of civility; it has a functional role 'to ease social tensions in order to facilitate social interaction and collaboration across differences and the resulting disagreements'. In this sense, civility as politeness acts as a 'lubricant' (Boyd 2006, 871) for social cooperation.

In this functional interpretation of civility (as politeness), one expresses only the kind of respect that is required to achieve the end of a well-functioning society. We are often polite for merely pragmatic/prudential reasons, for example, to guarantee a smooth social interaction with others and prevent conflict, especially in the short term, as in the aforementioned example of the polite racist politician. However, one can also be polite on moral grounds. Buss $(1999,795)$, for instance, has argued that manners are morally significant and that someone who is rude or discourteous is 'immoral as well as impolite'. However, this is because the kind of respect that Buss has in mind goes well beyond the mere acknowledgement that others should be tolerated and put up with because we have to live with them. Instead, Buss $(1999,796)$ is concerned

between these two components as a way to understand and explain the hierarchical relationships between the different dimensions of civility that we examine in the remainder of our analysis.

${ }^{9}$ Appraisal respect may also be involved in both politeness and public-mindedness. For example, we often assess and judge others' level of compliance with norms of politeness and etiquette, expressing disappointment if they are rude. Similarly, some believe that we should express moral disapproval and social stigma towards those who fail to comply with the constraints of justificatory civility (e.g., Rawls 2005, 445). However, in both cases, appraisal respect seems to concern the assessment of others' civility (or lack thereof) rather than the civility of the person who is doing the appraisal. 
with 'acknowledging a person's intrinsic value - treating her with respect'. According to her, this is not simply about putting up with others but about respecting them in the sense of acknowledging their dignity. It may therefore be the case that good manners and etiquette can sometimes signal something deeper than mere forbearance, that is, a commitment to recognizing and respecting others as free and equal members of society. When they do so, polite behaviours should be understood as instances of moral civility as much as of politeness. In many other cases, however, civility as politeness represents a mode of interaction that primarily displays or communicates one's pragmatic (that is, non-moral) recognition of 'one another as people among whom they must live' (Edyvane 2020, 95) through compliance with a particular set of social norms. It does not always need to involve a moral dimension tied to the idea of members of society as free and equal. ${ }^{10}$

Civility as public-mindedness relies on a different, more substantive and more demanding understanding of respect. Here, others should be respected as free and equal members, rather than as mere co-members, of society. More specifically, under justificatory civility 'to respect another person as an end is to require that coercive or political principles be as justifiable to that person as they presumably are to us' (Larmore 1999, 608). Alternatively, under moral civility, respecting others means viewing them as free and equal members of society entitled to certain rights and liberties. Respect in justificatory civility emphasizes the ability of others to reason and their equal status as co-legislators, whereas respect in moral civility highlights the dignity of others and their equal status as members of society entitled to certain rights and liberties. The reasons for displaying this kind of substantive respect are primarily moral ones. Usually, we want to tell others that we respect them as free and equal members of society because we actually view them as such, and that is why we believe that we have a duty to treat them with respect in the ways specified by justificatory and moral civility.

However, one could also imagine someone with pragmatic non-moral reasons to be civil in the justificatory or moral sense. This seems to be the case, for instance, when politicians appeal to public reasons not because they are genuinely convinced by them but because they believe their own comprehensive reasons-for example, those grounded in their religious views or sectarian partisan interest-to be widely unpopular. In such cases, the reason motivating their compliance with the rules of civility as public-mindedness and, more specifically, of justificatory civility is the hope of political gain, not a commitment to a principle of reciprocity or mutual respect. Is this politician being uncivil? We do not believe so. Commitment to public reason merely entails that the exercise of coercive power be justified by reference to public reasons, and this does not imply that these public reasons are the only reasons why we support the policy or that they are the reasons we personally regard as the most significant. To demand otherwise would be to set the bar of public reason very high indeed.

Therefore, a person who suppresses the fact that they support a political position on the basis of a comprehensive moral doctrine and instead appeals to a public reason is not uncivil in any sense, even if they do so in the hope of political gain. Civility, including justificatory civility, often requires restraining our speech (Calhoun 2000, 257). It involves, for example, 'the display of respect, tolerance, and consideration toward others no matter what we might privately think of them' (Calhoun 2000, 274-5, emphasis added). In the case of moral civility, this may require refraining from expressing racist or sexist views that one privately holds. When it comes to justificatory civility, restraint may demand instead refraining from appealing to one's comprehensive

\footnotetext{
${ }^{10} \mathrm{~A}$ range of possibilities exist between these two extremes. At one end, there is a purely pragmatic/non-moral politeness. At the other end, there is politeness that displays one's recognition of others as free and equal members of society. In between, we can find many instances where politeness does display a moral dimension but not one that involves treating others as free and equal. These might include, for example, acts of politeness by men towards women, or by aristocrats towards commoners, grounded in traditional, non-egalitarian, conservative moral worldviews. As Bejan $(2017,42)$ points out, for example: '[c]ivil worship [in early modern England] ... dealt paradigmatically with the performance of respect between unequals, usually from inferior to superior, including children to their fathers and subjects to their sovereign'.
} 
doctrines to justify political rules even if one privately thinks that those doctrines are true and are the only real reason why they believe a certain law or policy should be implemented. While this behaviour may still be morally reprehensible, for example, because it is insincere, ${ }^{11}$ it is not uncivil, ${ }^{12}$ since it still displays respect for others as free and equal.

Both pragmatic and moral reasons exist for complying with both dimensions of civility, though civility as politeness is more often associated with pragmatic reasons and civility as public-mindedness with moral ones. These different reasons, however, are not directly relevant considerations for deciding which kind of civility matters, when and why. We believe that the key to understanding how the different (sub-)dimensions of civility are normatively related is a focus on the different understandings of respect that each of them aims at communicating. What makes civility as politeness less important than civility as public-mindedness is not that it is primarily functional, but that the form of respect that it expresses is insufficient in a liberal democracy. This is why civility as public-mindedness should take priority over civility as politeness. The kind of respect that we, as members of liberal-democratic societies, ought to communicate to others is the more substantive understanding expressed in justificatory and moral civility.

This means that whenever people want to bring attention to the fact that they are not being respected as free and equal members of society, that is, that they are not being treated with the respect they are due, then they may no longer be bound by the rules of civility as politeness towards those who fail to be civil in a justificatory or moral sense towards them (see Edyvane 2020). The emphasis on the ends of the different dimensions of civility therefore supports the concerns that some critics have voiced against civility (Delmas 2018; Zerilli 2014) and suggests that violations of civility as politeness might be justified when people are 'denied full and equal status' (Delmas 2018, 63), that is, when there is a violation of civility as public-mindedness.

Furthermore, the two sub-dimensions of civility as public-mindedness also do not have the same level of importance: the moral dimension takes precedence and one can disregard the justificatory one in its absence. More specifically, when liberal-democratic norms and institutions are being violated in a society-for example, when a society allows slavery or gender discrimination - then one may use justificatory incivility in order to promote the goals of moral civility. Although Rawls does not make this distinction explicitly, prioritizing a commitment to liberaldemocratic values over the duty of public reason is clear in his aforementioned discussion of the US abolitionists. Their actions, he argues, 'supported political values of freedom and equality for all, but ... given the comprehensive doctrines they held and the doctrines current in their day, it was necessary [for them] to invoke the comprehensive grounds on which those values were widely seen to rest' (Rawls 2005, 251).

Here, a clarification is required. One might point out that the extent to which justificatory incivility can indeed advance moral civility depends on how justificatory civility is defined. In other words, our account presupposes that justificatory civility excludes religious reasons (for example, those employed by the US abolitionists) from public justification. However, perhaps this is an incorrect and overly narrow understanding of the constraints of public reason. For

\footnotetext{
${ }^{11}$ There is a body of literature focusing on the role of sincerity in public reason, where some authors argue that public reason demands that individuals only endorse political rules that they sincerely believe are justified based on public reasons (e.g., Gaus 1996, 139-40; Schwartzman 2011; for a critique, see Carey 2018). However, sincerity and civility are two different virtues and, it seems, they cannot always coexist when it comes to public reason. Sometimes, being civil entails being insincere.

${ }^{12}$ For those who are not politicians, it seems that compliance with the norms of justificatory and moral civility may more often be primarily moral: mere peaceful coexistence can already be achieved through politeness and there is often nothing further to be gained by refraining from appealing to our comprehensive doctrines or by explicitly acknowledging and defending the equal dignity of others. However, in some cases, people may comply with justificatory and/or moral civility for strategic reasons, for example, in order to appear 'nice' to others and thus obtain certain advantages (e.g., being promoted in the workplace, obtaining favours from friends and family, etc.).
} 
example, in a later formulation of his idea of public reason, the so-called 'wide view', Rawls (2005, 453) himself argued that non-public reasons (including religious ones) could be included in public deliberation 'provided that, in due course, we give properly public reasons to support the principles and policies our comprehensive doctrine is said to support'. This would seem to contradict the idea that when a person employs religious reasons to advance morally civil goals, they are being uncivil from a justificatory perspective. However, the Rawlsian proviso does not actually exempt religious persons from having to provide public reasons to justify the legislation they endorse. While the wide view of public reason allows more room for religious arguments in public deliberation, 'in due course', for example, at very latest before that legislation is passed and implemented, religious persons must also provide non-religious public reasons to justify it. At that point, their inability to do so could be considered an instance of justificatory incivility aimed at advancing a morally civil goal, if this is what the legislation they endorse does indeed aim to realize, as in the case of the abolitionists.

However, one could further object that it is wrong to consider all religious reasons as inherently non-public and therefore unsuitable for justificatory civility. Indeed for numerous authors (for example, Hertzberg 2019; Laborde 2017; March 2013; Waldron 2012b), it is misleading to construe the debate about the exclusionary character of public reason as a conflict between religious and secular reasons. We would like to focus specifically on Andrew March's (2013) work, which provides a useful categorization of different kinds of religious reasons, as well as different areas of legislation with respect to which these reasons can be employed. March's view is that not all religious reasons are in tension with political liberalism; a lot depends on what specific kinds of religious reasons they are and which kinds of political rules are being justified through them. For example, March $(2013,529)$ argues that appeals to 'scriptural, revealed, or clerical command' to justify restrictions of other people's rights and liberties, such as in the areas of homosexuality or divorce, are incompatible with a commitment to the liberal principle of legitimacy and the duty of civility. In these cases, the problem is both that ' $\mathrm{t}$ ] his is the category [of laws] where political liberalism is most concerned about the authoritarian and paternalistic influence of religious and other comprehensive, perfectionist arguments ... [and that] out of all forms of religious arguments ... scripturalist, authoritative, divine command arguments ... are the most authoritarian and theocratic' (March 2013, 533).

Conversely, March claims that religious reasons can sometimes be invoked to motivate fellow members of society to protect the independently justified rights and liberties of others, and that this need not violate the constraints of public reason. He mentions, for example, the contribution that religious arguments can make in the areas of social and racial justice, including global justice, the rights of future generations, and opposition to torture. With regard to the latter, for instance, he points out that '[o]ne does not need to be a Catholic to appreciate and learn from Catholic writings on dignity ... or believe in a divine Creator to be swayed by the claim that human life as such is sacred, or at least ought to be treated as if it is sacred' (March 2013, 529), and that torture is therefore wrong and should not be allowed. In this and similar cases, he adds, 'religious arguments are put into the public sphere in a form (not just a spirit) that does not require their original revealed or theistic premises in order to be publically [sic] intelligible' (March 2013, 529), and this prevents those who employ them from being uncivil.

Our critic might therefore conclude that this defies our characterization of the relationship between justificatory incivility and moral civility. The areas of legislation and types of policies with respect to which, according to March, advancing religious reasons does not seem to constitute an instance of incivility are precisely those that seem most closely related to the realization of morally civil goals. These include, for example, the promotion of various forms of social and racial justice, which clearly advances the interests of all members of society as free and equal, but not the prohibition of divorce or homosexual relationships, which involves the restriction of other people's rights and liberties. 
However, we are not entirely persuaded by this objection. Recall that March makes a twofold distinction: (1) between different types of religious reasons and (2) between different areas of legislation. While we accept that non-revealed, non-scriptural and non-clerical religious arguments invoked to advance morally civil goals, such as the protection of the rights of others as free and equal, may be consistent with justificatory civility, we are not persuaded that revealed, scriptural and clerical reasons invoked to advance the same goals are consistent with it, or at least not to the same extent. March $(2013,534)$ himself argues that 'Christian arguments for social justice from scripture or authority ... [are] not as authoritarian, theocratic, and disrespectful as equally scripturalist arguments about personal sexual decisions and individual citizens' access to important publicly distributed goods'. He points out that the former arguments are employed to support political rules that, unlike those restricting, say, the rights of homosexuals, are 'other regarding', 'not demeaning or humiliating' for those subject to them (for example, those whose resources are being redistributed) and 'not problematically paternalistic to the beneficiaries' (March 2013, 534-5).

However, and this is the crucial point, March does not say that the use of revealed, scriptural and clerical religious reasons in support of these kinds of laws and policies is not 'authoritarian, theocratic, and disrespectful', only that it is 'not as authoritarian, theocratic, and disrespectful' as the use of the same reasons in support of political rules that restrict other people's rights and liberties. In other words, even though March is not entirely explicit about this point, his analysis seems to imply that we should view justificatory civility and incivility as a matter of degree. Hence, we could categorize religious reasons' degree of compliance with justificatory civility in the following way, where 1 is the highest and 4 is the lowest degree:

1. Non-revealed, non-scriptural and non-clerical religious arguments invoked to advance the protection of the rights and liberties of others.

2. Revealed, scriptural and clerical religious arguments invoked to advance the protection of the rights and liberties of others.

3. Non-revealed, non-scriptural and non-clerical religious arguments invoked to justify restrictions of other people's rights and liberties.

4. Revealed, scriptural and clerical religious arguments invoked to justify restrictions of other people's rights and liberties.

Both 1 and 2, unlike 3 and 4, aim to advance morally civil goals, but 1 does so in a way that is fully compliant with justificatory civility, whereas this is only partially the case with 2 . In other words, 2 does constitute an instance of justificatory incivility, albeit a less significant one than 3 and 4 . In sum, at least some uses of religious reasons do constitute instances of justificatory incivility that can be employed to advance morally civil goals. Our argument therefore still stands, albeit in a qualified form.

To sum up, then, moral civility has priority over justificatory civility, and public-mindedness has priority over politeness. This hierarchy of relations is, however, only justified under non-ideal circumstances. Besides, even in non-ideal circumstances, it would be a mistake to overlook the important synergies between the different dimensions of civility. In our view, the true value of civility can only be grasped if civility as politeness and civility as public-mindedness (and, under the latter, justificatory and moral civility) are combined. The end of short-term peaceful exchange promoted by civility as politeness is not ambitious enough for liberal democracies that aim for equal respect among members of society, but equal respect is often impossible, or more difficult, without peaceful exchange. Treating politeness and public-mindedness as two independent aspects of civility seems to suggest that the set of norms associated with the former are irrelevant to the political purposes of the latter. This is a mistake. In our view, the ultimate purpose of civility should be to advance the common good by respecting others as free and equal members of society, which is the goal associated with civility as public-mindedness. 
However, compliance with the social norms of politeness can be a means towards the realization of civility as public-mindedness. By being polite, we can create the peaceful exchanges that are a precondition for both justificatory and moral civility. This new framework can also help us to better evaluate possible tensions between politeness and public-mindedness.

\section{When is (In)Civility a Problem?}

The distinction between different (sub-)dimensions of civility, together with the hierarchical relationships among them based on the type of respect that they aim at expressing, leads to a distinction between different dimensions of incivility. In the same way in which not all kinds of civility matter for the same reason, some kinds of incivility are more problematic than others. In fact, and somewhat paradoxically, incivility can sometimes be justified by civility itself.

Civility as politeness and civility as public-mindedness often appear together in people's speech and action. For example, when a group of medical student activists stand quietly in front of the provost's office with signs requesting that their university divest from tobacco companies in their financial portfolio, they are employing polite behaviour to advance a just cause that complies with the demands of public reason, that is their goal is to advance the common good by promoting public health. Civility as politeness, in this case, is a means employed to advance civility as public-mindedness. Conversely, when a politician uses rude and offensive language in public debate to advance political agendas that are centred around unjust and exclusionary values and goals, they are being uncivil in the two senses of the concept: their impolite language aims to advance non-public-minded goals. In both cases, we can say that these political actors are using their (in)civility as (im)politeness as a means to the end of (in)civility as (non-) public-mindedness. There is a functional congruence between their being (im)polite and their being (non-)public-minded. We call these 'deep politeness' and 'deep impoliteness', respectively. Furthermore, under civility as public-mindedness, when members of society use justificatory civility to advance moral civility, we call this 'deep civility'; conversely, when they are uncivil in the justificatory sense in order to undermine moral civility, we call this 'deep incivility'.

However, members of society may sometimes be polite while advancing sectarian ends that contravene public-mindedness. For example, a conservative politician may display high levels of civility as politeness by observing norms of etiquette and good manners when speaking in public forums, while justifying their preferred policies by appealing to controversial religious reasons grounded in their faith. In this case, civility as politeness is used as a means to realize a nonpublic end, thus violating justificatory civility. Likewise, 'polite Nazis' (Tiso 2017) may strategically comply with norms of civility as politeness in order to advance political agendas that fail to recognize members of some groups as free and equal members of society entitled to basic rights and liberties, thus contravening moral civility. Furthermore, as we saw earlier, one might comply with justificatory civility in order to defend or preserve social and political institutions that are not consistent with moral civility, for example, far-right political actors that appeal to liberal values, such as free speech and gender equality, in order to advance exclusionary (and, therefore, morally uncivil) political agendas.

In all these cases, there is a functional incongruence between civility as politeness and civility as public-mindedness or, under the latter, between justificatory civility and moral civility. One (sub-) dimension of civility is used to undermine rather than realize another. Since the ultimate purpose of civility, in our view, should be to advance the common good by respecting others as free and equal members of society, and since moral civility should have priority over both justificatory civility and civility as politeness, these behaviours are, at most, instances of surface-level civility, that is, superficially civil in the sense of politeness or justificatory civility but ultimately uncivil in the sense of moral civility. To distinguish between the two, we label them 'surface-level politeness', that is, politeness used to undermine public-mindedness in either its moral or justificatory dimension, and 'surface-level civility', that is, justificatory civility used to undermine moral civility. 
However, functional incongruence between civility as politeness and civility as publicmindedness can also manifest itself in the opposite way. The goal of civility as public-mindedness may sometimes be accompanied by impolite means: acts of dissent or civil disobedience may violate norms of civility as politeness while advocating more just institutions in line with the demands of civility as public-mindedness. Indeed, civility as public-mindedness may sometimes require behaviour that contradicts or challenges the established norms of civility as politeness. Meyer $(2000,72)$ observes that in serving the distinct interests of a society of citizens, and not those of polite society, liberal civility may not only sanction but also require behaviour - like indecorous, even at times rancorous, public disagreement - that is at odds with polite society'. Edyvane (2020) describes these kinds of challenges to civility norms as 'incivility as dissent', where incivility refers to violations of civility as politeness, as opposed to civility as publicmindedness. He suggests that instead of functioning as a one-off challenge to a particular institutional failure, incivility-as-dissent more often consists in recurring practices of small-scale rebellion inspired often by a nebulous sense of injustice' (Edyvane 2020, 105). ${ }^{13}$

Delmas (2018) even argues that there are circumstances where members of society have a political and moral duty to behave in an uncivil manner. For Delmas $(2018,10)$, a person's 'resistance to injustice, including through principled disobedience, is sometimes a better avenue to meet the demands of justice, fairness, Samaritanism, and political membership than legal compliance is, and ... uncivil acts of disobedience may preserve justice and democracy just as well as civil disobedience'. It is important to stress here that 'uncivil' in Delmas's account refers to the form of political action, particularly how this may contravene 'civility as decorum', that is, 'a dignified and polite manner' that avoids 'causing offense' (Delmas 2018, 43) - in other words, civility as manifested in social norms of politeness. For example, when some activists in the suffragette movement engaged in acts that violated different norms of politeness, ranging from norms of dress and good manners to norms against the disruption of daily life, they did so in order to advance more just political institutions, that is, civility as public-mindedness. ${ }^{14}$

In sum, incivility as impoliteness can be employed to advance civility as public-mindedness. Furthermore, as we stressed earlier, one may disregard the constraints of justificatory civility, for example, by invoking God, in order to promote liberal-democratic values and institutions or fight illiberal and undemocratic ones, such as slavery, thus advancing moral civility. Given the primacy that we assign to civility as public-mindedness over civility as politeness, and to moral civility over justificatory civility under the former, we consider these types of acts critically uncivil, that is, superficially uncivil in the sense of politeness or justificatory civility but ultimately civil in the sense of public-mindedness or, more specifically, of moral civility. To help differentiate between the two types of acts, we label them 'critical impoliteness', that is, impoliteness used to promote public-mindedness in either its moral or justificatory dimension, and 'critical incivility', that is, justificatory incivility aimed at advancing moral civility, respectively.

The key difference between our account of (in)civility and those of Edyvane and Delmas is that they view incivility as impoliteness as a means for realizing something other than civility, that is, justice. In our view, instead, (in)civility should be internally disaggregated and its impoliteness component viewed as a means for realizing its public-mindedness components. Furthermore, under the latter, justificatory civility should only be complied with if it helps realize, and does

\footnotetext{
${ }^{13}$ As we pointed out earlier, 'incivility as dissent' (Edyvane, 2020) can also be viewed as a potential response to the structural power asymmetries that often underlie norms of civility as politeness.

${ }^{14}$ However, for Delmas, acts of uncivil disobedience also include some violent acts, i.e., acts that based on our framework we would consider morally uncivil. This shows that tensions can exist not only between different dimensions of civility but also within the same dimension, in this case, moral civility. In other words, members of society may sometimes decide (and, according to Delmas, have a duty) to employ morally uncivil behaviour (e.g., violent acts) in order to advance morally civil goals (e.g., justice and equality) that they consider more important.
} 
not undermine, moral civility. The functional relationship at stake is one internal to (in)civility all the way down. ${ }^{15}$

All the examples of functional (in)congruence between different dimensions of civility discussed so far in this section result from intentional acts, that is, they concern agents who deliberately decide to use (in)civility as (im)politeness in order to realize (in)civility as (non-) public-mindedness. However, in some cases, incongruence may be unintentional. Take, for example, the practice of imposing the anglophone neologism 'Latinx' upon native Spanish speakers. The term 'Latinx' was first introduced in order to offer a gender-neutral alternative to 'Latino' (men) and 'Latina' (women), intending to be more inclusive towards non-binary and gender-fluid people (Love Ramirez and Blay 2016; van Horne 2016). In this sense, the introduction of 'Latinx' could be considered a way of changing language-related politeness norms in order to realize the morally civil end of recognizing all people as free and equal regardless of their gender identity, something that, according to advocates of this change, the use of the binary forms 'Latino' and 'Latina' previously precluded.

However, the use of 'Latinx' has been criticized by some for being an expression of anglophone linguistic imperialism, aiming to impose Anglocentric social norms upon Spanish speakers in ways that fail to respect their linguistic and cultural identity (Guerra and Orbea 2015). We suspect that this might be an instance of politeness signals going awry (see Bonotti and Zech 2021), that is, politeness signals being used with the intention of advancing a morally civil goal but instead being perceived by some as communicating a morally uncivil message of a different kind: members of certain linguistic and cultural groups need not treat members of other linguistic and cultural groups as free and equal and have the right to impose certain social norms upon them.

Furthermore, in this example, there also seems to be a tension internal to one of the dimensions of civility, that is, moral civility, as well as between different dimensions: some people want to advance morally civil goals in one way, that is, by promoting gender equality, but others in a different way, that is, by emphasizing the free and equal status of members of different linguistic and cultural groups. ${ }^{16}$ Some might, of course, disagree with us and argue that the imposition of the neologism 'Latinx' has not been unintentional. Of course, some might also insist that even if imposing this neologism involves a degree of linguistic and cultural imperialism, we should still embrace it since the promotion of the morally civil goal of gender equality ought to be prioritized over the morally civil goal of recognizing the equal status of different linguistic and cultural groups.

We recognize all these complexities, but regardless of what one's view on this matter is, we believe that our framework offers a particularly useful tool for better understanding and evaluating this case and, more generally, different instances of civility and incivility. More specifically, the analysis conducted in this article has revealed that disaggregating civility can help us to provide a more nuanced account than those that simply endorse or reject civility tout court, like recent defences of 'uncivil' disobedience (Delmas 2018). ${ }^{17}$ Civility, we have shown, is a complex

\footnotetext{
${ }^{15}$ As we explained earlier (see footnote 7), norms of moral and justificatory civility, like norms of civility as politeness, can vary between contexts and across time. This has implications not only for how we conceptualize each of the three dimensions of civility taken separately but also for how we understand the relationship between them. In other words, different (context-related) norms of civility as politeness may be employed to realize different (context-related) types of civility as public-mindedness. This will give rise to a variety of potential scenarios. For example, different societies may use different politeness norms to communicate the same kind of morally civil goal or use the same politeness norms to communicate different kinds of morally civil goals. We do not have the space here to analyse all these scenarios in their complexity. However, we believe that this kind of analysis should be central to future research on civility in normative political theory.

${ }^{16}$ This scenario is similar to the one we considered earlier (see footnote 14), where we highlighted the tension between different ways of realizing moral civility in connection with Delmas's (2018) account of uncivil disobedience, though in that case both morally civil and uncivil acts should be considered intentional.

${ }^{17}$ Debates on civil disobedience would benefit from a more explicit engagement with the literature on civility given the key role that the meaning of 'civility' plays in defining 'civil' disobedience. One of the few authors to have provided this kind of analysis is Milligan (2013), who proposes a 'minimalist account of civility'. According to Milligan (2013, 36), there are 'basic
} 
and multidimensional concept, and one need not view the choice between civility and incivility as a zero-sum game (see also Scheuerman, 2019). The (in) civility framework that we have defended helps us to better identify the potential relationships between different (sub-)dimensions of (in) civility; recognize whether and when tensions may occur between these different (sub-)dimensions or within the same (sub-)dimension; and understand that different actors may prioritize different (sub-)dimensions of (in) civility or different ways of realizing the same (sub-)dimension. By bringing all these considerations together into a unified and coherent framework, our analysis can also better guide policy interventions to promote civility and mitigate incivility, where necessary.

\section{Conclusion}

The concept of civility is increasingly central to both public and scholarly debate, yet its meaning often remains unclear. This article has made three central claims. First, civility should be disaggregated into two distinct but interconnected dimensions, that is, civility as politeness and civility as public-mindedness. The latter, in turn, involves both a justificatory sub-dimension and a moral sub-dimension. Second, there is a hierarchical relationship between civility as politeness and civility as public-mindedness. The latter should hold primacy over the former. Furthermore, under civility as public-mindedness, moral civility should be prioritized over justificatory civility. Third, and finally, there is a functional relationship between (in)civility as (im)politeness and (in)civility as (non-)public-mindedness. Politeness can be used to advance both public-minded (deep politeness) and non-public-minded (surface-level politeness) goals. Conversely, impoliteness can be used to advance both non-public-minded (deep impoliteness) and public-minded (critical impoliteness) goals. Likewise, justificatory civility can be used both to advance moral civility (deep civility) and to undermine it (surface-level civility). Conversely, justificatory incivility can be used to advance either moral incivility (deep incivility) or moral civility (critical incivility).

Acknowledgements. The authors have benefitted from feedback provided by numerous colleagues. They are particularly thankful for comments from participants at the Civic Virtue in Public Life Workshop at Monash University, December 2019, and at the University of Milan SPS Seminar, February 2020. Furthermore, they appreciate feedback from members of the Melbourne Political, Legal and Social Theory Network. Finally, the authors are grateful to Paul Bou-Habib and to three anonymous reviewers for their insightful and constructive comments on earlier versions of the article.

Financial Support. This work is part of a larger collaborative project titled 'Civic Virtue in Public Life: Understanding and Countering Incivility in Liberal Democracies'. The research is funded as part of the Self, Virtue and Public Life Project, a three-year research initiative based at the Institute for the Study of Human Flourishing at the University of Oklahoma, made possible with generous support from the Templeton Religion Trust. The authors are especially grateful to Nancy Snow and Mechelle Gibson at the University of Oklahoma for their invaluable support.

Competing Interests. None.

\section{References}

Bejan TM (2011) The bond of civility: Roger Williams on toleration and its limits. History of European Ideas 37(4), 409-420. Bejan TM (2017) Mere Civility: Disagreement and the Limits of Toleration. Cambridge, MA: Harvard University Press. Bonotti M and Zech ST (2021) Recovering Civility during COVID-19. Singapore: Palgrave Macmillan.

Boyd R (2006) The value of civility? Urban Studies 43(5-6), 863-878.

norms that any protest must not violate or break beyond a certain point if it is to stay within civil bounds'. Such norms include: 'respect of others' or 'the recognition that other humans are fellow humans'; 'the rejection of hate speech'; 'the avoidance of acts which are driven by hatred'; 'the largely successful commitment to try to avoid violence and threats of violence'; 'the avoidance of cruelty'; and 'an avoidance of the reckless endangerment of others' (Milligan 2013, 36). These norms seem to be mainly related to what we call 'moral civility'. A more comprehensive analysis of the relationship between civility and civil disobedience should also consider the role of civility as politeness and justificatory civility. This is an issue that we do not have the space to further examine here. 
Brown A (2015) Hate Speech Law: A Philosophical Examination. New York, NY, and Abingdon, Oxon: Routledge.

Buss S (1999) Appearing respectful: the moral significance of manners. Ethics 109(4), 795-826.

Calhoun C (2000) The virtue of civility. Philosophy \& Public Affairs 29(3), 251-275.

Carey B (2018) Public reason - honesty, not sincerity. The Journal of Political Philosophy 26(1), 47-64.

Carter SL (1998) Civility: Manners, Morals, and the Etiquette of Democracy. New York, NY: Basic Books.

Castelli Gattinara P (2017) Framing exclusion in the public sphere: far-right mobilisation and the debate on Charlie Hebdo in Italy. South European Society and Politics 22(3), 345-364.

Christiano T (2012) What is civility and how does it relate to core democratic values? In Clayton CW and Elgar R (eds), Civility and Democracy in America: A Reasonable Understanding. Pullman, WA: Washington State University Press, pp. 108-118.

Cohen J (2012) Reflections on civility. In Clayton CW and Elgar R (eds), Civility and Democracy in America: A Reasonable Understanding. Pullman, WA: Washington State University Press, pp. 119-123.

Daly E (2015) Ostentation and republican civility: notes from the French face-veiling debates. European Journal of Political Theory 14(3), 297-319.

Darwall SL (1977) Two kinds of respect. Ethics 88(1), 36-49.

Delmas C (2018) A Duty to Resist: When Disobedience Should Be Uncivil. Oxford: Oxford University Press.

Edyvane D (2017) The passion for civility. Political Studies Review 15(3), 344-354.

Edyvane D (2020) Incivility as dissent. Political Studies 68(1), 93-109.

Elias N (1969) The Civilizing Process: The History of Manners. Oxford: Blackwell.

Feinberg J (1985) Offense to Others: The Moral Limits of the Criminal Law, Volume 2. Oxford: Oxford University Press.

Flanders C (2012) The mutability of public reason. Ratio Juris 25(2), 180-205.

Freud S (2004) Civilization and Its Discontents. London: Penguin.

Gaus G (1996) Justificatory Liberalism: An Essay on Epistemology and Political Theory. Oxford: Oxford University Press.

Goffman E (1959) The Presentation of Self in Everyday Life. New York: Anchor Books.

Greve JE and Pilkington E (2020) Nancy Pelosi rips up Trump's speech after divisive State of the Union address. The Guardian, 5 February. Available from https://www.theguardian.com/us-news/2020/feb/04/nancy-pelosi-trump-speechrips-up-handshake-snub-state-of-the-union (accessed 24 October 2021).

Guerra G and Orbea G (2015) The argument against the use of the term 'Latinx'. The Phoenix, 19 November. Available from https://swarthmorephoenix.com/2015/11/19/the-argument-against-the-use-of-the-term-latinx/ (accessed 24 October 2021).

Harcourt BE (2012) The politics of incivility. Arizona Law Review 54(2), 345-373.

Hertzberg B (2019) Chains of Persuasion: A Framework for Religion in Democracy. New York, NY: Oxford University Press.

Kekes J (1984) Civility and society. History of Philosophy Quarterly 1(4), 429-443.

Laborde C (2017) Liberalism's Religion. Cambridge, MA: Harvard University Press.

Laden AS (2019) Two concepts of civility. In Boatright RG et al. (eds), A Crisis of Civility? Political Discourse and Its Discontents. New York, NY: Routledge, pp. 9-30.

Lægaard S (2010) A multicultural social ethos: tolerance, respect or civility? In Calder G and Ceva E (eds), Diversity in Europe. Abingdon and New York, NY: Routledge, pp. 93-108.

Larmore C (1999) The moral basis of political liberalism. The Journal of Philosophy 96(12), 599-625.

Love Ramirez T and Blay Z (2016) Why people are using the term 'Latinx'. HuffPost, 5 July. Available from https://www. huffpost.com/entry/why-people-are-using-the-term-latinx_n_57753328e4b0cc0fa136a159 (accessed 24 October 2021).

Macedo S (1992) Charting liberal virtues. Nomos 34, 204-232.

Manning PK (1976) The decline of civility: a comment on Erving Goffman's sociology. Canadian Review of Sociology 13(1), 13-25.

March A (2013) Rethinking religious reasons in public justification. American Political Science Review 107(3), $523-539$.

Meyer MJ (2000) Liberal civility and the civility of etiquette: public ideals and personal lives. Social Theory and Practice 26(1), 69-84.

Milligan T (2013) Civil Disobedience: Protest, Justification and the Law. London: Bloomsbury.

Peterson A (2019) Civility and Democratic Education. Singapore: Springer.

Pippin R (2005) The ethical status of civility. In The Persistence of Subjectivity: On the Kantian Aftermath. Cambridge: Cambridge University Press, pp. 223-238.

Rawls J (1999) The Law of Peoples. Cambridge, MA: Harvard University Press.

Rawls J (2005) Political Liberalism (Expanded Edition). New York, NY: Columbia University Press.

Sabl A (2005) Virtue for pluralists. Journal of Moral Philosophy 2(2), 207-235.

Salam D (2019) Public reason: a stranger in non-liberal and religious societies? Philosophy \& Social Criticism 45(1), 3-26.

Scheuerman WE (2019) Why not uncivil disobedience? Critical Review of International Social and Political Philosophy, 16 November, pp. 1-20, doi: 10.1080/13698230.2019.1693158.

Schwartzman M (2011) The sincerity of public reason. The Journal of Political Philosophy 19(4), 375-398.

Shils EA (1997) The Virtue of Civility: Selected Essays on Liberalism, Tradition, and Civil Society. Indianapolis, IN: Liberty Fund. 
Sinopoli RC (1995) Thick-skinned liberalism: redefining civility. American Political Science Review 89(3), 612-620.

Strachan JC and Wolf MR (2012) Political civility: introduction to political civility. PS: Political Science \& Politics 45(3), 401-404.

Tiso G (2017) On polite Nazis and the violence of speech. Overland, 6 December. Available from https://overland.org.au/ 2017/12/the-violence-of-speech/ (accessed 24 October 2021).

Van Horne P (2016) Writer Jack Qu'emi explains the meaning of 'Latinx'. The World, 21 June. Available from https://www. pri.org/stories/2016-06-21/writer-jack-quemi-explains-meaning-latinx (accessed 24 October 2021).

Waldron J (2012a) The Harm in Hate Speech. Cambridge, MA: Harvard University Press.

Waldron J (2012b) Two-way translation: the ethics of engaging with religious contributions in public deliberation. Mercer Law Review 63(3), 845-868.

Zerilli L (2014) Against civility: a feminist perspective. In Sarat A (ed.), Civility, Legality, and Justice in America. Cambridge: Cambridge University Press, pp. 107-131.

Zurn CF (2013) Political civility: another idealistic illusion. Public Affairs Quarterly 27(4), 341-368.

Cite this article: Bardon A, Bonotti M, Zech ST, Ridge W (2023). Disaggregating Civility: Politeness, Public-Mindedness and Their Connection. British Journal of Political Science 53, 308-325. https://doi.org/10.1017/S000712342100065X 